\title{
Correlation Between Stress Level and Learning Motivation of Pre-Clinical Medical Student in Faculty of Medicine Universitas Airlangga
}

\author{
Rieza Rizqy Alda ${ }^{1}$, Budi Utomo² ${ }^{\star}$, Helmia Hasan ${ }^{3}$
}

${ }^{1}$ Faculty of Medicine, Universitas Airlangga, Surabaya, Indonesia.

${ }^{2}$ Department of Pulmonology, Faculty of Medicine, Universitas Airlangga, Surabaya, Indonesia. ${ }^{3}$ Department of Public Health, Faculty of Medicine, Universitas Airlangga, Surabaya, Indonesia.

\section{A B S T R A C T}

Introduction: Stress is mental health problem that can occur to medical student. Stress distract student's life from student's task. This distraction causes ineffective study. Ineffective study could cause lower motivation and probability of educational failure.

Methods: This study was a cross-sectional analytic that used pre-clinical medical student in Faculty of Medicine Universitas Airlangga as population. This study used convenience/haphazard sampling as sampling method. The data was taken at Faculty of Medicine Universitas Airlangga from June to August of 2018. The subjects that meet the criteria were subjects who agreed to informed consent. The data was taken using questionnaires. The questionnaires were DASS (Depression Anxiety Stress Scales) and MSLQ (Motivated Strategies of Learning Questionnaire). The data then was examined for normality.

Results: A total of 95 medical students were included in this study, 55 subjects were female, mostly aged 21 years old. Most of pre-clinical medical student's stress level was on normal level (47.5\%), while their motivation level was on adequate level $(74.7 \%)$.

Conclusion: There is a correlation between stress level and learning motivation of pre-clinical medical student in Faculty of Medicine Universitas Airlangga.

* Correspondence: budiutomo@fk.unair.ac.id

JUXTA: Jurnal IImiah Mahasiswa Kedokteran Universitas Airlangga

p-ISSN: 1907-3623; e-ISSN: 2684-9453

DOI: $10.20473 /$ juxta.V11/12020.18-22

Open access under Creative Commons Attribution-ShareAlike 4.0 International License

(CC-BY-SA)
ARTICLE INFO

\section{Article history:}

Received 12 August 2019

Received in revised form 21

August 2019

Accepted 22 January 2020

\section{Keywords:}

Learning motivation,

Stress level,

Medical student. 


\section{Introduction}

Stress can be defined as a condition or feeling in which an individual feel that he has demands placed above his power or ability. ${ }^{1}$ Stress can affect an individual's behaviour patterns and biological processes due to the effectiveness of the stressor response. Chronic stress exposure can cause permanent psychological, emotional, and behavioural changes. ${ }^{2}$

A study conducted in University of North Sumatra stated that out of 100 medical students who were taken randomly, $35 \%$ were at mild stress levels, $61 \%$ at moderate stress levels, and $4 \%$ at severe stress levels. ${ }^{3} \mathrm{~A}$ similar study in Iran also showed out of 100 medical students who were taken randomly, $26.22 \%$ were at the level of mild stress, $20.5 \%$ were at the level of moderate stress, and $14.75 \%$ in severe stress. ${ }^{4}$

A stressor will trigger the work of the autonomic nervous system which functions to regulate the body's work. In the autonomic nervous system there is a sympathetic nervous system, which when given a stressor will increase its activity. One of the activities is sending signals to the adrenal gland to produce stress hormones. Stress hormones changes are commonly called the fight or flight response. ${ }^{5}$

Pre-clinical students are different from clinical students or intern in terms of stressors. Pre-clinical student's source of stress include the vastness of the academic curriculum, fear of failure and poor results during exams, lack of time for recreation, relationship, food quality, loneliness, family problems and competition. ${ }^{6}$

When someone faces a stressor, he/she will resist. The resistance will be done by adjusting or adapting to alleviate problems. The self-adaptation of an individual with another individual is very different depending on the two interactions between the strength or scale of the stressors received and the sensitivity of the individual. This adaptability has several factors, such as maturity that is influential in decision making, the principle of framework to find rationality in a problem, and emotions in the overall psychological state. ${ }^{7}$

Coping is a defence mechanism to overcome exposure to stressors which is a burden for a person's mental state. Every living creature has problems, and each of them will try to find a way out. Someone who experiences stress will try to overcome the stress that requires a decision maker. There are many coping strategies such as task-oriented, emotion-oriented, and avoidance oriented. ${ }^{8}$

Someone needs a reason to do something. Important reasons and emergencies will encourage someone to do something. Reasons can be anything that encourages people to do something like motivation. ${ }^{9}$ Motivation comes because of self-awareness. Awareness is needed to know one's own abilities, so that someone is able to determine the size of the output needed to get things done. These aspects are encouragement, commitment, initiative, and optimism. ${ }^{10}$ Encouragement arises for some reasons, and reasons arise because of a will. Humans always want to fulfil their desires so that with all their power, they will accomplice them. The process of fulfilling the desire requires commitment to ensure continuity, so that it will be quickly fulfilled. Every process requires a trigger to move, so an initiative is needed to start one. This initiative is needed to protect from setbacks, thus stability is needed.

Learning motivation is an example of extrinsic motivation. The encouragement arises not because someone finds pleasure in learning as the main focus, but rather emphasizes its instrumental value as an effort to process in facing the test and get the best score as a graduation requirement. ${ }^{11}$
This study aims to determine the correlation between stress level and learning motivation of pre-clinical medical student in Faculty of Medicine Universitas Airlangga.

\section{Methods}

\section{Subject}

The sample in this study was an active pre-clinical student at the Faculty of Medicine Universitas Airlangga with the total of 95 students. The subjects were taken with concept of haphazard sampling which is a technique for taking subjects from populations that are present at the time and placed intentionally when encountered or accessed with the criteria of willingly accept informed consent, and excluding students that did not give back questionnaires.

This study was conducted at Faculty of Medicine Universitas Airlangga from June to August 2018.

\section{Procedure}

Data collection was done by means of primary data collection from responses using questionnaires. The questionnaire was a set of questions/statements that had been prepared. The questionnaire used must be validated according to the instrument used.

Data collection was done right after the lecture or at a time based on the theory that has the possibility of the results obtained approaching the actual results. Data collection was done by explaining in advance the rules and procedures before filling out the questionnaire.

Selected subjects who agreed to informed consent were allowed to fill out questionnaires by writing down their identity. After filling in their identity and other data, the subjects were allowed to fill out a questionnaire consisting of two parts, Depression Anxiety Stress Scales (DASS) questionnaire to assess stress levels, and Motivated Strategies of Learning Questionnaire (MSLQ) questionnaire to assess motivation levels. The questionnaire was collected by the author directly and processed to determine the value.

The data went through the process of editing, coding, entry, scoring, and cleaning. The editing process included was crosschecking data that was unclear or incomplete to the subject of the study aimed at avoiding error results. The coding process was done to simplify data entry and data analysis by grouping or categorizing. After data entry was done, the next process was scoring based on the provisions of the validated measuring instruments. Components of descriptive statistics, such as percentages, averages, and standard deviations, were used to describe data. Categorical variables were presented in percentages. Rechecking the data was needed to be done before the value data was processed into the results of analysis. This process is called cleaning.

The analysis was carried out by the univariate method, and bivariate correlation to determine the distribution, frequency, distribution and correlation between the two variables. This study obtained a non-parametric data so the correlation analysis used was Spearman correlation.

\section{Results}

The results of this cross-sectional analytic study obtained stress level data in the form of independent variable, while the dependent variable was learning motivation level. 


\section{Characteristics of Subjects}

The age of the research subjects obtained was in the range of 18 to 24 years. The research subject was dominated by the age of 21 years. Distribution of research subjects based on age can be seen in the following table.

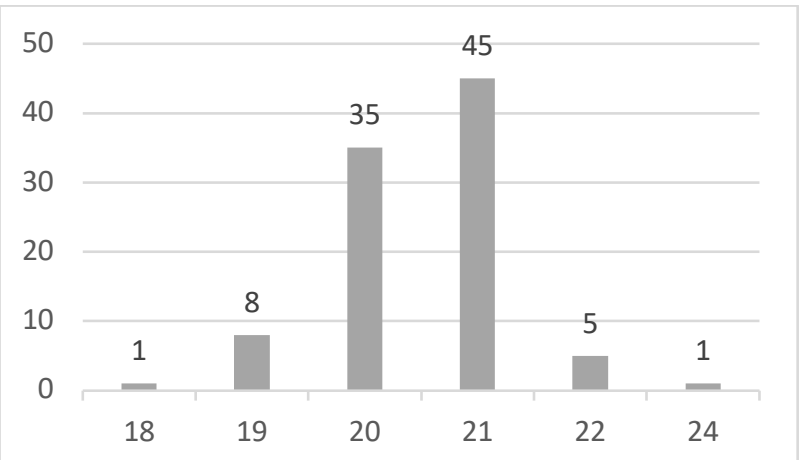

Figure 1. Distribution of subjects based on age. female.

The table below shows $57.9 \%$ of data obtained was

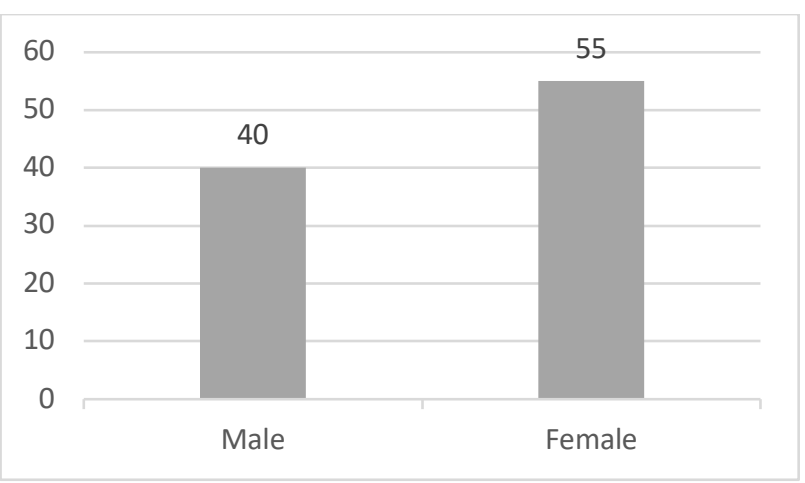

Figure 2. Distribution of subjects based on sex.

\section{Data Results}

Table 1. Distribution of stress levels.

\begin{tabular}{lll}
\hline Stress Level & Frequency & Percentage (\%) \\
\hline Normal & 45 & 47.4 \\
Mild & 19 & 20.0 \\
Moderate & 19 & 20.0 \\
Severe & 12 & 12.6 \\
\hline Total & 95 & 100 \\
\hline
\end{tabular}

Table 1 shows the highest number of stress levels at the normal level of $47 \%$, followed by mild and moderate stress of $20 \%$, and $12.6 \%$ that is severe stress.

Table 2. Distribution of learning motivation level.

\begin{tabular}{|c|c|c|}
\hline $\begin{array}{l}\text { Learning Motivation } \\
\text { Level }\end{array}$ & Frequency & Percentage (\%) \\
\hline Low & 8 & 8.4 \\
\hline Adequate & 71 & 74.7 \\
\hline High & 16 & 16.9 \\
\hline Total & 95 & 100 \\
\hline
\end{tabular}

Table 2 shows the highest number at adequate motivation level of $74.7 \%$ followed by high motivation level of $16.8 \%$, and $8.4 \%$ by low motivation level.

\section{Analysis and Study Results}

Table 3. Distribution of correlation between stress level and motivation level of learning.

\begin{tabular}{llcc}
\hline Stress Level & $\begin{array}{c}\text { Learning } \\
\text { Motivation Level }\end{array}$ & Total & $\begin{array}{c}\text { Percentage } \\
(\%)\end{array}$ \\
\hline \multirow{3}{*}{ Normal } & Low & 5 & 5.3 \\
& Adequate & 36 & 37.9 \\
& High & 4 & 4.2 \\
\multirow{3}{*}{ Mild } & Low & 2 & 2.1 \\
& Adequate & 14 & 14.7 \\
& High & 3 & 3.2 \\
Moderate & Low & 1 & 1.1 \\
& Adequate & 13 & 13.7 \\
& High & 5 & 5.3 \\
Severe & Low & 8 & 8.4 \\
& Adequate & 4 & 4.2 \\
& High & 12 & 12.6 \\
\hline Total & & 95 & 100 \\
\hline
\end{tabular}

Data analysis process within this study started with normality test by applying One-Sample KolmogorovSmirnov Test. In this study both stress levels and learning motivation data were not distributed normally. Therefore, in this study, the analysis used Spearman's rank correlation as non-parametric test items.

Table 4. Normality test results.

\begin{tabular}{|c|c|c|}
\hline Variable & $P$ value & Commentary \\
\hline Learning Motivation Level & 0.001 & $\begin{array}{c}\text { not } \\
\text { distributed } \\
\text { normally }\end{array}$ \\
\hline Stress Level & 0.001 & $\begin{array}{c}\text { not } \\
\text { distributed } \\
\text { normally }\end{array}$ \\
\hline
\end{tabular}

On Spearman's rank correlation test, it was revealed that $p$ value in this study is 0.014 . The value of $p<0.05$ indicates that there is a (meaningful) correlation between both variables, with correlation coefficient value is 0.252 . The value of the correlation coefficient is positive, indicating the correlation between the two variables is weak and unidirectional or one way.

Table 5. Spearman's rank correlation test result.

\begin{tabular}{lccc}
\hline \multicolumn{1}{c}{ Variable } & $p$ value & $\begin{array}{c}\text { correlation } \\
\text { coefficient }\end{array}$ & Commentary \\
\hline $\begin{array}{l}\text { Learning } \\
\text { Motivation } \\
\text { Level }\end{array}$ & 0.014 & 0.252 & $\begin{array}{c}\text { there is a } \\
\text { correlation }\end{array}$ \\
Stress Level & & &
\end{tabular}

\section{Discussion}

The results of this study found that $47.4 \%$ of the preclinical students of Faculty of Medicine Universitas Airlangga had a good mental state, while $20 \%$ experienced mild stress, $20 \%$ moderate stress, and $12.6 \%$ severe stress. The results of this study stated that the most stress levels possessed by medical students were at normal levels.

Research conducted by Wahyudi, et al., (2015) found that the highest stress level possessed by first-year medical students was moderate stress with a percentage of $57.23 \%$ followed by $22.89 \%$ mild stress, $17.47 \%$ severe stress, and $2.41 \%$ was very heavy. ${ }^{12}$ Comparison of the results conducted by Wahyudi with this study show a level called the research subject, namely the level of moderate stress levels. The difference can be caused by the existing university, city, and cultural environment. Environmental differences can cause stress levels experienced by 
students, for example university numbers, number of students in one class, and others. Differences can occur individually, such as sleepwear, study habits, and rest periods. ${ }^{13}$

Research conducted by Raudah found that $6.3 \%$ of students had low learning motivation levels, $75 \%$ of students had adequate learning motivation levels, and $18.8 \%$ of students had high levels of learning motivation. ${ }^{14}$ There is a comparison of the results conducted by Raudah with this study. This equation was done by the formulas used, namely medical faculty and its students, which consist of various places, developing and existing culture.

This study found that there is a relationship between stress levels and learning motivation in pre-clinical students at Faculty of Medicine Universitas Airlangga ( $p$ value $<0.05)$. These results indicate that there is relation between stress levels ranging from normal condition to severe stress and motivation levels ranging from low to high motivation. The results of this study do not describe the influence between variables, but describe the two-way relationship between the two variables. The two-way relationship in question is a way of determining the hypothesis of the presence or absence of a relationship with an unclear direction.

Research conducted by Puspitha stated that there was a relationship between stresses on learning motivation of first-level students of the medical faculty. The results of the study support the hypothesis and the results obtained in this study with the same research subject. ${ }^{15}$ Research conducted by Raudah stated that there was a relationship between stress on learning motivation of medical faculty students with $p$ value $0.001 \quad(p<0.05) .{ }^{14}$ Research conducted by Raudah supports the results of this study, so the results obtained in this study are getting stronger. The difference between the research conducted by Raudah and this study is at the time of sampling. Research conducted by Raudah was conducted when medical faculty students were working on scientific papers.

Stress as a psychological state of an individual can influence output in the form of actions and behaviour. This is because the self-adjustment process is done by taskoriented or ego-oriented defence mechanism which will form a coping mechanism in the form of strategies and patterns. The level of self-adjustment is influenced by stress intensity and individual adjustment power, such as maturity, education level, and mental strength. This process of adjustment will lead to a better and more efficient process of mental improvement. ${ }^{7}$

Every individual has basic psychological needs, such as the desire to be loved, involvement in something, selfesteem, and freedom. If there is a disruption or obstruction to meet these needs, then the individual will carry out the defence mechanism of the ego because his/her integrity is being threatened. This mechanism is also experienced during learning or lectures. Needs that occur during learning are self-involvement because of self-esteem, demands that must be fulfilled for recognition of the environment, and freedom that is perceived as contrary to regulations. When needs are not met, a signal arises from the mind to find a way out. This compensation mechanism will influence the choice of strategy and style of coping mechanism according to the durability and stress intensity of a unique individual. ${ }^{16}$

The desire to fulfil basic needs can also be described by the level of motivation, because motivation is the desire, action, and needs that can encourage an individual. This push action can be observed in an individual in the form of behaviour. Motivation to learn is an act of encouragement to learn something, so that learning motivation is more influenced by extrinsic motivation. Extrinsic motivation is based on the value of the instrument which is more valuable than the individual ego needs. Motivation to learn has the value of an instrument that is more valuable because an individual learns not to seek pleasure alone but because of the benefits to be gained. ${ }^{11}$

The direction of the relationship on stress levels with the motivation level in this study is in the same direction (correlation coefficient +0.252). The purpose of one direction is when one variable at a level then the other variables follow at the same level. From this point of view, if the student's stress level is low or normal then the level of motivation is also low, and if the stress level is high then the level of motivation is also high.

The research conducted by Raudah found a correlation coefficient of $0.627 . .^{14}$ These results are in line with the results of this study which state that the relationship between stress and motivation is in the same direction, but there are differences in the strength of the relationship between the two. The difference in strength of the relationship between stress and motivation can occur due to environmental influences that affect self-protection mechanisms that can influence coping mechanisms. ${ }^{8}$

The research conducted by Demolingo obtained a correlation coefficient of $-0.219 .{ }^{17}$ The research conducted by Mulya and Indrawati obtained a correlation coefficient of $-0.525 .^{18}$ Both of these results are not in line with the results of this study which state the relationship between stress and motivation has opposite characteristics. The differences can be caused by several factors, including the unique characteristics of the subject of research, the environment, and learning behaviour. The characteristic in question is the character of medical faculty students having a high awareness and more knowledge of mental health. The environment in question is culture and social life such as friendship, norms in society, and religious values embraced. Learning behaviour is learning time, rest or recreation time from learning, and learning methods that will affect a person's quality in learning. These factors are discrete in nature, each person has different factors that can influence them ${ }^{9}$.

This study uses three subprogram level students as research subjects who have different triggers and stress factors than other levels, for example, the students are conducting research as final assignments and have different lecture hours.

This study has many factors that influence the results, so the variables can show different results. This is compounded by traits that cannot be directly observed.

\section{Conclusion}

Based on the results of data analysis from this study, the results showed that the majority of pre-clinical students were at normal or not stressed levels, and the majority had learning motivation at a sufficient level. There is a correlation between the level of stress and motivation to learn in pre-clinical students of Faculty of Medicine Universitas Airlangga. Therefore, further research is needed on another level of medical education to compare the result and discover problems that exist in the field.

\section{CONFLICT OF INTEREST}

The author stated there is no conflict of interest in this study. 


\section{REFERENCES}

1.Stress TAIO. What is Stress?: (2017).

2.Cohen S, Janicki-Deverts D and Miller GE. Psychological Stress and Disease. Jama. 2007; 298: 1685-7.

3.Pathmanathan VV. Gambaran Tingkat Stres pada Mahasiswa Fakultas Kedokteran Universitas Sumatera Utara Semester Ganjil Tahun Akademik 2012/2013 e-jurnal Fakultas Kedokteran USU. 2013; 1: 2-5.

4.Marjani A, Gharavi AM, Jahanshahi M, Vahidirad A and Alizadeh F. Stress among Medical Students of Gorgan (South East of Caspian Sea), Iran. Kathmandu University Medical Journal (KUMJ). 2008; 6: 421-5.

5.Li C-T, Cao J and Li TMH. Eustress or Distress: An Empirical Study of Perceived Stress in Everyday College Life. 2016, P.1209-17.

6.Anuradha R, Dutta R, Raja JD, Sivaprakasam P and Patil AB. Stress and Stressors among Medical Undergraduate Students: A Cross-Sectional Study in a Private Medical College in Tamil Nadu. Indian Journal of Community Medicine : Official Publication of Indian Association of Preventive \& Social Medicine. 2017; 42: 222-5.

7.Sharma S. Adjustment: Process, Acheivement, Characteristics, Measurement and Dimensions. 2016.

8.Kausar R. Perceived Stress, Academic Workloads and Use of Coping Strategies by University Students. Journal of Behavioural Sciences. 2010; 20: 31-45.

9.Sadock BJ, Sadock VA and Ruiz P. Kaplan and Sadock's Synopsis of Psychiatry: Behavioral Sciences/Clinical Psychiatry. 11th ed. Philadelphia: Lippincott Williams \& Wilkins, 2015.

10.Cherniss C and Goleman D. The Emotionally Intelligent Workplace. San Francisco: Jossey-Bass, 2001.
11.Ryan RM and Deci EL. Intrinsic and Extrinsic Motivations: Classic Definitions and New Directions. Contemporary Educational Psychology. 2000; 25: 54-67.

12.Wahyudi R, Bebasari E and Nazriati E. Gambaran Tingkat Stres pada Mahasiswa Fakultas Kedokteran Universitas Riau Tahun Pertama. Jurnal IImu Kedokteran. 2017; 9: 107.

13.Ross SE, Neibling BC and Heckert TM. Sources of Stress among College Students. College Student Journal. 1999; 33: 312-7.

14.Raudah F, Budiarti LY and Lestari DR. Stres dengan Motivasi Belajar Mahasiswa Reguler Fakultas Kedokteran UNLAM yang sedang Menyusun Karya Tulis IImiah (KTI). Jurnal Dunia Keperawatan. 2015; 3: 44-55.

15.Puspitha FC. Hubungan Stres terhadap Motivasi Belajar Mahasisa Tingkat Pertama Fakultas Kedokteran Universitas Lampung. Lampung: Universitas Lampung, 2017.

16.Vaillat GE. Ego Mechanisms of Defense and Personality Psychopathology. Journal of Abnormal Psychology. 1994 103: 44-50.

17.Demlingo DPA, Kalalo $F$ and Katuuk ME. Hubungan Stres degan Motivasi Belajar pada Mahasiswa Semester V Program Studi IImu Keperawatan Fakultas Kedokteran Universitas Sam Ratulangi Manado. Jurnal Keperawatan. 2018; 6.

18.Muly HA and Indrawati ES. Hubungan antara Motivasi Berprestsi dengan Stres Akademik pada Mahasiswa Tingkat Pertama Fakultas Psikologi Universitas Diponegoro Semarang. 2017. 2017: 7. 